\title{
Perceptions of mothers about the quality of life of children with hydrocephalus
}

\author{
Percepções de mães acerca da qualidade de vida de crianças com hidrocefalia
}

Carliane Evangelista Buriti Torres ${ }^{1}$, Ádria Marcela Vieira Ferreira ${ }^{2}$, Leidiane Minervina Moraes de Sabino ${ }^{2}$, Mariana Cavalcante Martins ${ }^{2}$, Francisca Amanda Martins Couto ${ }^{1}$, Viviane Mamede Vasconcelos Cavalcante ${ }^{2}$

Objective: to understand the perceptions of mothers about the quality of life of children with hydrocephalus. Methods: qualitative research carried out in a pediatric public hospital with twelve mothers of children with hydrocephalus. Data were collected from semi-structured interviews and the content analysis was performed. Results: according to the mothers, children with hydrocephalus had a considerable motor deficit, but some managed to perform this function properly. The emotional status had not presented a significant change, and in relation to school performance, the majority was not studying in school or could not keep up with the learning rhythm of the others, however, they managed to maintain good interpersonal relationships. Conclusion: children with hydrocephalus presented deficits in motor, educational and emotional development, but they had no impairment in interpersonal relationships, according to mothers' perceptions.

Descriptors: Hydrocephalus; Quality of Life; Child.

Objetivo: compreender as percepções de mães acerca da qualidade de vida de crianças com hidrocefalia. Métodos: pesquisa qualitativa, realizada com doze mães de crianças com hidrocefalia, em um hospital público pediátrico. Dados coletados a partir de entrevistas semiestruturadas e realizada análise de conteúdo. Resultados: de acordo com as mães, as crianças com hidrocefalia possuíam déficit motor considerável, porém algumas conseguiam desempenhar essa função adequadamente. 0 estado emocional não apresentou alteração importante; e com relação ao desempenho escolar, a maioria não estudava ou não conseguia acompanhar o ritmo de aprendizado das demais, contudo, mantinham bom relacionamento interpessoal. Conclusão: as crianças com hidrocefalia apresentaram déficit nos desenvolvimentos motor, educacional e emocional, porém sem prejuízos no relacionamento interpessoal, de acordo com as percepções maternas.

Descritores: Hidrocefalia; Qualidade de Vida; Criança.

${ }^{1}$ Faculdade da Grande Fortaleza. Fortaleza, CE, Brazil.

${ }^{2}$ Universidade Federal do Ceará. Fortaleza, CE, Brazil. 


\section{Introduction}

Hydrocephalus occurs due to the excessive accumulation of cerebrospinal fluid in the cerebral ventricles, causing ventricular dilation and compression of the nervous system ${ }^{(1)}$. Its causes may be congenital or acquired. The former is present at birth and may be caused by environmental factors during fetal development or genetic predisposition. "Silvio's aqueduct stenosis" and spina bifida are common causes ${ }^{(1)}$. It is worth mentioning the higher incidence of congenital alterations in developing countries, such as Brazil, reaching a percentage of 3.16/1,000 newborns ${ }^{(2)}$.

Acquired hydrocephalus can affect people of all ages; the most common causes are: intraventricular hemorrhage, meningitis, brain abscess, head trauma and arachnoid cysts ${ }^{(1)}$. Signs and symptoms vary according to patient's age, primary cause or underlying disease, presence of other malformations or associated brain lesions, extent of obstruction to cerebrospinal fluid flow and level of intracranial pressure ${ }^{(3)}$.

The clinical symptoms characterizing this pathology are most frequently identified from the second and third year of life. They manifest in the acute (headache, vomiting, oculomotor symptoms, deterioration of the level of consciousness, convulsions and papilloedema) or chronic form of the disease (morning vomiting, progressive deterioration of gait, retardation in neuropsychomotor development and behavioral alterations). It can also evolve to complete dependence on activities of daily living in the most severe $\operatorname{cases}^{(3)}$.

Hydrocephalus becomes particularly important in childhood, as these symptoms can directly affect the child's development and quality of life, especially in relation to emotional, social and school aspects ${ }^{(4)}$.

Quality of life can be characterized as a value attributed to life from the present functional deteriorations or perceptions that are induced by diseases ${ }^{(5)}$; and its evaluation is therefore necessary for the child with hydrocephalus. This evaluation requires a multidimensional approach, since it may involve subjective parameters such as well-being, happiness and perso- nal fulfillment; and objective parameters related to the satisfaction of basic needs and those emerging in a given social structure ${ }^{(6)}$.

A study revealed that hydrocephalus involves issues related to one's own illness and family $\operatorname{aspects}^{(7)}$, which makes valid the investigation of maternal perceptions about the quality of life of children with hydrocephalus. Therefore, considering that children with hydrocephalus suffer from recurrent hospitalizations and need differentiated care, it is necessary to know the aspects that may be compromised, based on the interpretation of the mothers' perceptions, so that the quality of life of children is promoted with this change.

It is important to highlight the role of the nurse in the care of the child with hydrocephalus, who presents during hospitalizations complications, such as pressure ulcer, neurogenic bladder, risk of infection and pain, which requires the early identification and performance of the professional ${ }^{(8)}$. In addition, nursing care is not restricted to hospital care, but mainly to the orientation of the continuity of this care at home, for which knowledge about the quality of life of children is relevant to meet their real needs.

Therefore, the present study is relevant, inasmuch it will provide subsidies for nurses to work on strategies to improve the quality of life of children with hydrocephalus and on the orientation of mothers and/or caregivers on individualized care at home. The objective was to understand the mothers' perceptions about the quality of life of children with hydrocephalus.

\section{Methods}

This is a qualitative research, carried out in a public reference hospital in pediatric tertiary care, located in Fortaleza-CE, Brazil. The institution is currently divided into blocks, one of which is dedicated to specialized care for children hospitalized with hydrocephalus, in which there are ambulatories reserved to continue the individualized treatment of each child 
followed-up in the hospital.

Twelve mothers participated in the study, according to established inclusion criteria: mothers of children aged from zero to 12 years with hydrocephalus who had been hospitalized or in an outpatient clinic at the referred hospital at the time of the research. It was established as exclusion criterion: mothers of children with other neurological pathologies that could influence the association between quality of life and hydrocephalus.

Data collection took place in October and November 2015 through a semistructured interview with a questionnaire for sociodemographic characterization (age, marital status, family income, schooling, origin, among others). At this point, the interviewer was free to develop each situation in the direction he considered appropriate, in order to explore the issue widely ${ }^{(9)}$. The questions made were: how do you evaluate your child's physical performance (walking, running, practicing physical activity, bathing etc.)? How do you evaluate your child's emotional state (how has he/she slept? What feeling does he/she most often demonstrate during the day?) Does he/she have frequent mood swings? What is your child's relationship with other children and/or adults? How is your child's school life/performance? This last question was directed only to mothers who had children who were studying. The interviews were recorded in voice recorder.

The questions were based on the Pediatric Quality of Life questionnaire ${ }^{(10)}$. The content analysis was carried out in three stages: reading of the content, exploration of the material and elaboration of an interpretative synthesis by means of an essay ${ }^{(11)}$. Participants signed a permission term to record the interview. In order to respect ethical aspects and keep anonymity, their names have been replaced by codes (P1, P2, P3, ..., P12).

The study complied with the formal requirements contained in the national and international regulatory standards for research involving human beings.

\section{Results}

In the characterization of the 12 mothers, single women were predominant $(n=8 ; 67.0 \%)$. The age ranged from 21 to 41 years of age, with prevalence of the age range from 21 to 30 years old ( $n=6 ; 50.0 \%)$. The level of education ranged from illiteracy to complete high school, but half had completed primary education ( $n=6 ; 50.0 \%)$. The monthly income of the majority was less than or equal to a minimum wage $(n=9 ; 75.0 \%)$. As for housing, the majority had their own home $(n=7 ; 58.0 \%)$ and lived in the interior of the State $(n=7 ; 58.0 \%)$.

Of the 12 children with hydrocephalus, the majority were female $(n=7 ; 58.0 \%)$, and were between one and five years old $(n=9 ; 75.0 \%)$. Half of them were not enrolled in school ( $n=6 ; 50.0 \%)$, of whom five were in the age group of one to five years, and only one in the age group of 6 to 12 years. The other children were enrolled in the pre-school and primary education.

Ten children (83.0\%) has been diagnosed soon after birth and two (17.0\%) has been diagnosed during the gestation period. Pediatricians ( $n=4 ; 33.0 \%)$, obstetricians $(n=3 ; 25.0 \%)$, neonatologists $(n=3 ; 25.0 \%)$ and neurologists $(n=2 ; 17.0 \%)$ were the professionals who related to the discovery of the diagnosis.

After analyzing the transcribed interviews, two thematic categories emerged: Physical, emotional and school domains of the child with hydrocephalus and Interpersonal relationship.

\section{Physical, emotional and school domains}

Motor function, especially gait, is the most impaired in children with hydrocephalus, as verified in the speeches of mothers of children between two and five years: She still does not walk, but the physiotherapist has already said that she will be able to walk; she will be a normal child (P2). He is all weakened like that; he does not walk; he does not cry. He has such a movement in the legs, you know, and a little in the arms, but he can also move them. He is mostly like this, with little movements (P11). He does not walk. Everything in him is too calm; he does phy- 
siotherapy; they have even sent him to the orthopedist. Even because his cannot bend his knee (P7).

It was also possible to observe children who could achieve good motor performance: She walks, she runs, she jumps, she talks; she does everything. No one says she has a problem, only who knows it, but she does not appear to have (P12). In the beginning, the doctor would tell me he did not know if she was going to walk, because she had myelomeningocele, but she had a chance. She had done physiotherapy in the water, until she was three years old. She walks normally, speaks normally, has a normal life (P6). He runs well, but I do not let him run, not to fall, so nothing happens in the valve. He walks like us (P9).

Regarding the mothers' perceptions on the emotional domain, the reaction of the children with hydrocephalus does not differ much from the others, as they seem to feel and to demonstrate feelings: $P e o-$ ple say children like that do not understand a thing, you see, because when I play with her, she smiles and when I talk seriously with her, like "stop it, daughter, stop", she looks at me and makes a sad face (P1). No, for sure, he feels the affection, surely. He feels we are talking to him, surely he feels the affection. But in his case, he really shows it ... what, what, no. In his case, he does not (P11).

Different from other children, at certain times they also show irritation/anger: He is joyful, but he gets angry when he is irritated (P4). She is very joyful, but she is angry, she wants things in her time, has many wills (P12).

The school domain has shown to be deficient, especially aggravated by the pathology in question, making it difficult for children aged over two years to learn: It is very weak, because if he wants to do the homework, he does, but if he does not want to, he does not do it. The teachers do not care. He cannot read, he cannot write, not even his name, he does not know how to write down the words in the board (P5). Well, we used to receive a support for him, he was still starting. Then, when this thing arose, I did not let him go anymore, he liked it so much, he woke up alone, asked to go to school, and it's because it was at morning (P7). He does not study (P8).

However, it was possible to find children with satisfactory school performance: He is very well-behaved at school; I receive no complaints of him from school. (P9). She is starting to do homework now, because this is already the second year that she's staying. But it demands special care, but she is keeping up (P10).
Everyone there likes her. And she keeps it up everything (P12).

As observed, according to the mothers' perceptions, the majority of children with hydrocephalus presented deficits in school life, but some have achieved acceptable performance, satisfactorily following the rhythm of other children in the classroom.

\section{Interpersonal relationship}

Children with hydrocephalus face many obstacles that limit their independence and ability to fulfill what society considers normal, such as difficulty in interpersonal relationships.

In this study, some mothers have shown that it is possible to have good relationships with these children, since they are able to understand what happens around them: She likes it, she pays attention, when someone talks to her, she keeps looking, wanting to talk, makes a sad face. (P1). She likes to play, she gets along, she likes to make friends. (P10).

The children could show affection for the other: She is very affectionate, she does not fight, none of this, no. She is very affectionate; she just does not like that people takes her things (P12). Super funny, they watch movies together, she knows how to differentiate Patati, the Galinha Pintadinha [children's Brazilian TV characters]. I turn on the TV for them to watch and whenever different things are on, she keeps watching. She watches everything (P2).

On the other hand, in this context of the interpersonal relationship, the patient can be seen with disturbance: If someone treats him well, he will treat well, but if someone treats him with aggression, he is aggressive as well. But he is very affectionate, you know, he is very careful (P5). She is easily upset, she yells. She is like this, cannot see a child (P6).

\section{Discussion}

The results of the study had limitations because they were based only on the mothers' perceptions, without considering the physical evaluation of the child. However, it is reinforced that it was possible to achieve the established objective, as well as to present data to support future research and to strengthen knowledge about the quality of life of children with hydrocephalus. 
It is known that family socioeconomic aspects affect care for people with hydrocephalus ${ }^{(7)}$. Despite the insertion of women into the labor market, the role of mothers as caregivers of their children is still common, providing better health care ${ }^{(12)}$, as seen in this study. With regard to schooling, complete primary education is identified as crucial to ensuring the quality of care for children with hydrocephalus, as studies have shown families' schooling as essential for maintaining children's health and for adequately providing care $^{(13)}$.

Monthly income less than a minimum wage is an important problem that must be taken in consideration, as it may indirectly impair the quality of life. Often, mothers of children with hydrocephalus report that they experience financial difficulties because the resources available are insufficient to defray the child's food, displacement and consumption material $^{(14)}$.

The quality of life of children with hydrocephalus may be affected by the impairment of neurological functions due to the pathology, such as motor skills, learning, attention and behavior. A study developed in children with brain tumors revealed that, based on the use of the Pediatric Quality of Life Inventory scale, those with hydrocephalus had lower physical quality of life scores when compared to children without hydrocephalus ${ }^{(15)}$.

Regarding the physical domain, this study found that gait was impaired, but it was also possible to observe children with good motor performance, presenting motor function close to a child who does not present pathologies, that is, being able to perform what is expected for the age in which they are. A research performed with children with hydrocephalus corroborates these findings, since it has shown that motor skills can suffer losses at different levels, since of the five children evaluated, two demonstrated a greater impairment of motor function, while the others presented greater neuromotor ability ${ }^{(16)}$. It should be emphasized that there may be improvement of this motor function from the treatment and care perfor$\operatorname{med}^{(17)}$.
Although the physical domain has suffered some interference by the clinical characteristics of the disease in relation to the emotional domain, the children in this study did not differ much from the others, because they could demonstrate feelings through smiles and irritations. In addition, children with hydrocephalus, when exposed to different situations, as sensorial stimulus, present extreme discomfort associated with irritability ${ }^{(14)}$.

A study of parents of children with hydrocephalus showed that the latter had neuropsychological performance below the standard considered normal, but parents reported that the children had quality of life similar to other children who did not present hydrocephalus ${ }^{(4)}$, as highlighted by the mothers in this study.

However, the school domain is usually affected by learning and communication deficits. As observed in this study, most children with hydrocephalus did not study or had a deficit in school life, although some achieved acceptable performance, satisfactorily following the rhythm of other children in the classroom. Previous research corroborates this result, in which the parents of children with hydrocephalus pointed out that they presented difficulties in physical, school and social health, thus interfering in the quality of life $^{(4)}$.

The most frequent difficulties in the communication of children with hydrocephalus are preservation, when the information of a dialogue is repeated; echolalia, when they repeat what another person says instead of producing an adequate response; hyperverbal communication, when they do not stop talking, besides the speech is inappropriate for the situation; problems of comprehension, with difficulty in answering adequately to the questions ${ }^{(1)}$.

Another important limitation is the difficulty of these children with interpersonal relationships, which may result in social isolation ${ }^{(6)}$. Even so, as observed in the mothers' speeches, the children in this study were able to show affection towards the other. This can be a consequence of the maternal dedication and the formation of a bond of the caregiver with the cared 
child, thus stimulating affectivity and generating positive return. The maternal dedication in the care of the child with hydrocephalus is full time, in order to improve the clinical picture of the child and to provide a better quality of life, so that the mother neglects even her role as wife ${ }^{(18)}$.

However, the family context is not always faced positively, considering that some mothers reported in their speeches the concern about the child. This disturbance is possibly a consequence of the stress caused by the daily need for special and full-time care. A recent study with children with hydrocephalus up to six months of age found that symptoms of stress were present in $95.0 \%$ of caregivers ${ }^{(19)}$.

Considering the above, it is possible to observe that children with hydrocephalus can demonstrate interpersonal relationships in different ways, either by interacting with others, being affectionate by touch, or even being poorly understood and seen as a disturbance.

Thus, the present study may contribute to the development of future research that proposes to carry out interventions aimed at the physical, emotional and scholar development of children with hydrocephalus, as well as to improve the interpersonal relationship and quality of life.

\section{Conclusion}

Children with hydrocephalus have presented deficits in motor, educational and emotional development, but without impairment in interpersonal relationships, according to the mothers' perceptions.

\section{Collaborations}

Torres CEB and Couto FAM contributed to the conception and design, analysis and interpretation of data. Ferreira AMV and Sabino LMM contributed to the writing of the article and critical and relevant review of the intellectual content. Martins MC and Vasconcelos VM contributed to the final approval of the version to be published.

\section{References}

1. Garcia ET, Hueso NP. Estudio de las características básicas de la hidrocefalia en la infancia y adolescência. Rialaim [Internet]. 2013 [citado 2017 jun. 24]; 3(1):44-51. Disponível em: https:// www.researchgate.net/publication/276997485_ Estudio_de_las_caracteristicas_basicas_de_la_ hidrocefalia_en_la_infancia_y_adolescencia

2. Melo R, Melo EN, de Vasconcellos AG, Pacheco P. Congenital hydrocephalus in the northeast of Brazil: epidemiological aspects, prenatal diagnosis, and treatment. Childs Nerv Syst. 2013; 29:1899-903. doi: http://dx.doi.org/10.1007/ s00381-013-2111-y

3. Cunha AHGB. Hidrocefalia na infância. Rev Bras Neurol Psiquiatr [Internet]. 2014 [citado 2017 Jun. 12]; 18(2):85-93. Disponível em: https://rbnp. emnuvens.com.br/rbnp/article/view/74/35

4. Mikkelsen R, Rodevand LN, Wiig US, Zahj SM, Berntsen T, Skarbo AB et al. Neurocognitive and psychosocial function in children with benign external hydrocephalus (BEH)-a long-term followup study. Childs Nerv Syst; 2017; 33(1):91-9. doi: https://doi.org/10.1007/s00381-016-3267-z

5. Takiuti ME, Girardi P, Carvalho ALO, Nakano T, Silva MF, Hueb TO. The application of surveys of quality of life in coronary artery disease. RBM [Internet]. 2013 [citado 2017 out. 09]; 70(6):226. Disponível em: http://www.moreirajr.com.br/ revistas.asp?fase $=$ r003\&id_materia $=5406$

6. Vitorino LM, Paskulin LMG, Vianna LAC. Quality of life of seniors living in the community and in long term care facilities: a comparative study. Rev Latino-am Enfermagem. 2013; 21(Spec):311. doi: http://dx.doi.org/10.1590/S010411692013000700002

7. Oliveira DMP, Pereira CU, Freitas ZMP. Aspects of the ingestion of folic acid among pregnant caregivers of children with hydrocephalus. Pediatr Mod [Internet]. 2014 [cited 2017 July 1]; 50(4):169-72. Available from: http://www. moreirajr.com.br/revistas.asp? fase $=$ r003\&id_ materia $=5746$ 
8. Cestari VRF, Carvalho ZMF, Barbosa IV, Melo EM, Studart RMB. Nursing care to the child with hydrocephalus: an integrative literature review. Rev Enferm UFPE on line [Internet]. 2013 [cited 2017 Oct 11]; 7(5):4112-8. Available from: http://www.revista.ufpe.br/revistaenfermagem/ index.php/revista/article/view/3070/pdf_2465

9. Sampieri RM, Collado CF, Lucio MDPB. Metodologia de pesquisa. Porto Alegre: AMGH; 2013.

10. Varni JW, Seid M, Rode CA. The PedsQL: measurement model for the pediatric quality of life inventory. Med Care [Internet]. 1999 [cited 2017 June 23]; 37:126-39. Available from: https:// insights.ovid.com/pubmed?pmid=10024117

11. Minayo MCS, Deslandes SF, Gomes R. Pesquisa social: teoria, método e criatividade. Rio de Janeiro: Vozes; 2013.

12. Pantenburg B, Ochoa TJ, Ecker L, Ruiz J. Feeding of Young children during diarrhea: caregivers' intended practices and perceptions. Am J Trop Med Hyg. 2014; 91(3):555-62. doi: http://dx.doi. org/10.4269/ajtmh.13-0235

13. Sims-Williams HJ, Sims-Williams HP, Kabachelor EM, Fotheringham J, Warf BC. Ten-year survival of Ugandan infants after myelomeningocele closure. J Neurosurg Pediatr. 2017; 19(1):70-6. doi: http:// dx.doi.org/10.3171/2016.7.PEDS16296

14. Costa ECL, Veloso RA, Feitosa JJM. Crianças portadoras de hidrocefalia: dificuldades e vivência das mães. R Interd [Internet]. 2013 [citado 2017 Jun. 14]; 6(1):71-9. Disponível em: http:// revistainterdisciplinar.uninovafapi.edu.br/index. php/revinter/article/view/17/pdf_9
15. Kulkami AV, Piscione J, Shams I, Bouffet E. Long-term quality of life in children treated for posterior fossa brain tumors. J Neurosurg Pediatr. 2013; 12(3):235-40. doi: https://doi. org/10.3171/2013.6.PEDS12535

16. Bilate IC. Análise da motricidade das crianças com diagnóstico de hidrocefalia: um estudo realizado na enfermaria pediátrica do Hospital Geral de Vitória da Conquista/BA. Rev Eletr Fainor [Internet]. 2014 [citado 2017 Jun. 4]; 7(2):33-41. Disponível em: http://srv02.fainor. com.br/revista/index.php/memorias/article/ view/305/191

17. Korhonen VE, Solje E, Suhonen NM, Rauramaa T, Vanninen R, Remes AM, et al. Frontotemporal dementia as a comorbidity to idiopathic normal pressure hydrocephalus (iNPH): a short review of literature and an unusual case. Fluids Barriers CNS. 2017; 14(1):10. doi: https://doi.org/10.1186/s12987-017-0060-7

18. Rocha MCP, Carvalho MSM, Fossa AM, Pedroso GER, Rossato LM. Necessidades e dificuldades de famílias que vivenciam a experiência de ter uma criança com hidrocefalia. Saúde Rev. 2015; 15(40):49-66. doi: http://dx.doi. org/10.15600/2238-1244/sr.v15n40p49-66

19. Melo JRT, Vieira KA, Miranda T. Stress in caregivers of children with hydrocephalus. Rev Bras Neurol Psiquiatr. 2014 [cited 2017 June 14]; 18(1):3-12. Available from: https://rbnp.emnuvens.com.br/ rbnp/article/view/23/22 